\title{
The Headmaster's Strategy to Improve Civil Servants' Work Performance (Administration Department) in Pringgasela High School, East Lombok-NTB
}

\author{
Parhan $^{\text {a* }}$, Soesilo Zauhar ${ }^{\mathrm{b}}$, Sarwono ${ }^{\mathrm{c}}$, Bambang Santoso Haryono ${ }^{\mathrm{d}}$ \\ ${ }^{a}$ bcd Universitas Brawijaya, Malang, East Java, Indonesia
}

\section{ARTICLE INFORMATION}

\section{Article history:}

Data submission : 10 June 2020

$1^{\text {st }}$ revision: 10 August 2020

Accepted: 16 November 2021

Available online: 10 December 2021

Keywords: headmaster's strategy, civil servant, work performance

\section{ABSTRACT}

This study aims to determine the headmaster's strategy to improve the work performance of Civil servant [administration department] at Pringgasela Senior High School. This research used the descriptive qualitative research method. The data in this study were obtained from interviews with informants and documentation. The data analysis was carried out in the following steps: data collection, data reduction, data presentation and drawing conclusions or verification (Miles and Huberman, 2014: 20). The results of this study stated that the headmaster's strategy to improve the work performance of civil servants in the administration department: Making disciplinary rules about working hours that must be on time. Building a spirit of togetherness through civil servants' friends, superiors and subordinates, as well as communication, intimacy and mutual respect. Providing role models for all civil servants. The results of the headmaster's strategy show the work performance of civil servants [administration department] is classified good in providing services, however they have not provided satisfaction to: teachers, students or other related parties. As for the constraints faced when performing performance in providing services, by the Administrative Apparatus such as the lack of responsiveness of the Administrative Apparatus in understanding consumer psychology, the large amount of workload that is carried out in a little bit of time and the supporting infrastructure is inadequate and lack of personel.

2021 FIA UB. All rights reserved.

\section{Introduction}

Schools are complex and unique institutions. It is complex because schools have various dimensions which are interrelated and mutually determine each other. Meanwhile, the unique character indicates that the school as an organization has certain characteristics that are not shared by other organizations. The characteristics that place schools have their own character, where there is a teaching and learning process, a place for culture, life and people. (Wahjosumidjo, 2005).

In line with efforts to improve a better working atmosphere in an educational institution in the form of a school led by the headmaster, the current headmaster improves his functions and duties in the school institution. The headmaster must strive so that all the potential in his school both in the human resource as well as in the tools, equipment, finance and so on to achieve the goals as well as possible. The headmaster must be someone who masters administration. Physically, the principal must have the ability to manage the curriculum, manage student administration, manage personnel administration, facilities and infrastructure and also finance.

The headmaster has an important role as the manager in the school. Therefore, as a manager he must have a leadership spirit in management, as well as regulating teachers, school administration / administration staff and other civil servants. In this case, the principal is not only managing teachers, but also administrative duties,

\footnotetext{
* Corresponding author email: bahasparhan@gmail.com
} 
students, school relations with the community and parents of students. To be able to achieve school goals is depends entirely on the policies implemented by the headmaster. The school principal has great authority in making school-level policies, so that the school has more ability to develop the potential for itself and its environment.

The main duties of the headmaster consist of four patterns, they are: (1) The leader, as the head of the school, the headmaster should move all the potential of the school to achieve the school goals, (2) The administration manager, the headmaster is in charge to carry out his school administration, (3) The Reformer, the headmaster is in charge to update the condition of his school, (4) The supporter, the headmaster is in charge to give support in the learning process in schools there is a subsystem / component that is interrelated. One of these subsystems / components is the school administration staff. The presence of these personnel will greatly support the improvement of education quality and services if they have the minimum qualifications and competencies. In addition, the competence possessed will reflect the Good Governance process. Fulfilling the qualification and competency standards for school administrative staff at the primary and secondary education levels in a position is a right that must be fulfilled by school administrators.

Therefore, Administration department as one of the operational management activities carries out the following activities: (1) Receiving, recording and processing outgoing and incoming mail, (2) Taking care of storage, maintenance and preservation of archives, (3) Organizing and serving the necessary archive for the headmaster and other parties who need it as soon as possible, (4) Taking care of the storage and stamps, (5) Preparing and processing draft letters, (6) Taking care of procurement of forms, cards and other stationery, (7) Managing communication and relationships with outsiders, (8) Implementing other activities from superiors.

Improving the professionalism and commitment of school administration staff in order to improve the relevance, efficiency and accountability of education is important. In order for the school administrative staff to be able to carry out their main duties and functions properly, therefore human resources must work optimally in carrying out their main duties and functions as school. Administrative staff who are considered still lacking in term of their work performance in school in the field of administrative staff will affect the school to achieve their goal. If the performance of the school administration staff is in accordance with what has been determined, then this can answer the government's desire to improve the quality of education.

\section{Theory}

\subsection{The Concept of Strategy}

The term strategy according to the Siagian (2000) originally came from the military and is popularly often stated as a "tips" used by the generals to win a war. Nowadays, the term strategy has been used by all types of organizations and the main ideas contained in the original meaning are maintained, but their application is adjusted to the type of organization. Because in a real sense, top management is involved in a particular form of warfare.

Thus, in general, it can be said that the word strategy in the management of an organization can be interpreted as a tips, method and main tactics designed systematically in carrying out management functions that are directed at the goals of organizational strategy (Nawawi, 2000). If the definition is said to be the strategy of the headmaster at Pringgasela High School in an effort to improve the performance of the civil servant in the school administration department in this study, it is intended as tips, methods and tactics of the principal to improve the performance of civil servant in school administration, so that they are more capable to carry out their duties as a civil servant by providing excellent services.

Ensuring a strategy can be successful or not depends on the existence of consistency between the strategy and its implementation. However, that does not mean that strategy is not a main guide for implementation, because the philosophy of strategy formulation is to bridge the organization with its environment so that it is possible to have an adaptive creativity but still relevant to the existing situation and conditions (Bryson, 2007).

The effective strategy must meet several criteria (Bryson, 1995). First, the strategy is technically feasible. Second, it is politically acceptable to important stakeholders. Third, it must be in accordance with the philosophy and values of the organization. Fourth, strategies must also become ethical, moral, legal and to be a better organizational activity. And fifth, it must also be in accordance with the strategic issue to be solved. From the previous statement, it is clear that strategy for organizational management is a large-scale plan that is oriented towards a distant future and is determined in such a way to allow the organization to interact effectively with the environment in conditions of competition, all of which are directed towards optimizing the achievement of organizational goals and objectives (Siagian, 2003).

The headmaster as an educator (teacher), in carrying out his role must have the right strategy to improve the professionalism of educational personnel in his school for example a strategy of implementing an attractive learning model. Duties \& roles of a headmaster (Regulation of Minister of Education and Culture Number 6 of 2018) referring to Article 15 of regulation Number 6 of 2018 concerning the Assignment of Teachers as the headmaster is stated that the Main Duties and Functions of the headmaster are stated as follows:

a) The entire workload of the headmaster is to carry out managerial, entrepreneurial development, and supervision of teachers and education personnel.

b) The headmaster's workload aims to develop schools and improve it quality based on 8 (eight) national education standards.

c) When there is a shortage of teachers in a certain education unit, the headmaster can carry out learning 
and guidance tasks so that the learning and guidance process continues in the relevant education unit.

d) The headmaster who carries out the task of learning or mentoring, the task of learning or mentoring is an additional task beyond the main task.

e) The workload for the headmaster who are placed in SILN in addition to carrying out the workload also carries out the promotion of Indonesian culture.

There are tiga functions of the headmaster: as the educational administrator, as the education supervisor; and as the education leader. The efforts that can be made by the headmaster to improve his performance as an educator, especially in improving the performance of the teaching staff and the learning achievement of students can be described by upgrading teachers and administrative staff by widen the knowledge of teachers and administrative staff. The headmaster must also provide administrative personnel to increase knowledge and skills by studying for a higher level of education, for example providing opportunities for teachers and administrative personnel who have not reached the bachelor's level to attend lectures at universities close to schools whose implementation does not interfere with learning activities.

\subsection{Administration Department Duties at School}

Service is the activity of a person, group and or organization, either directly or indirectly, to fulfill needs (Siagian, 2003). The delivery of public services is an attempt by the State to fulfill the basic needs and civil rights of every citizen, and the State is obliged to provide services to all citizens. Because if the community is not satisfied with the performance of administrative staff, their wishes and demands are not heard, their rights is locked, access and public opportunities are hampered, it cannot be completely blamed if the community then protests and they are disappointed and expresses their frustration to the school principal. Public servants do not deliver customer service, they deliver democracy (government employees do not work to serve customers, but to realize democratic values). Furthermore, he stated that: Government shouldn't be run like business, it should be run like democracy, (Government should not be run like a company, but serve society democratically), such as honestly, equitably, fairly, not discriminatory, and accountable. Therefore, the realization of quality public services is one of the characteristics of good governance and this is what the principal targets in order to assess administrative performance.

\subsection{Definition of the Civil Servant (ASN) Law Number $5 / 2014$}

The civil servant is a profession for civil servants and government employees with work agreements who work for government agencies. Civil Servants of the State are civil servants and government employees with a work agreement appointed by officials of the state and assigned to work in a government position or assigned to other state duties and are paid based on statutory regulations.

Administration is the activity of collecting, holding, recording, duplicating, storing and sending various useful information data to realize the main tasks of the organization. (Nawawi, 2000). The administration department whether in schools, offices, or other institutions is an important part and is quite busy and is the most frequently visited. Starting from registering prospective students, managing new apparatus files, issuing the decree, processing diplomas, managing promotion files, to legalizing diplomas. It can be said that all paperwork and data recording matters such as data on agency members, finance, and other data are the responsibility of the administration department. In general, the notion of administration is a part of administration that specifically manages data starting from collecting or collecting, recording, processing, duplicating, sending, to storing data. Administration is responsible for collecting data or information from those that do not exist yet or from scattered to collect so that they can be used when needed.

The productivity of school administrators is not only intended to get the maximum results, but it is also important to pay attention to the quality of work. Individual productivity can be assessed from what the individual does in his work for example how he does the job or the work performance. In this case, productivity can be reviewed based on its level with respective benchmarks, which can be seen from the performance of the education staff, it can be interpreted as work performance.

Performance has a close relationship with productivity because it is an indicator to determine efforts in order to achieve a high level of organizational productivity. In this connection, efforts to assess organizational performance are important. Talking about the performance of the personnel, it is closely related to the assessment of the work of the teacher so that it is necessary to set performance standards or performance standards. Performance standards need to be formulated as a benchmark in making comparisons between what has been done and what is expected, in relation to the job or position entrusted. Standards can also be used as a measure in holding accountability for something that has been done (Alewine, 2002).

According to Herzherg's theory, as described in Siagian (2003) the factors that act as a motivator for civil servant which are are able to satisfy and encourage people to work well consist of:
a) Achievement
b) Recognition
c) The work it self
d) Responsibilities
e) Advancement

Efforts to move the civil servants to carry out their work according to the wish of the leader, then presumably the leadership can pay attention to several factors that affect the motivation of these subordinates. Factors that influence these civil servants are the existence of a clear measurement for the performance of civil servant at schools is felt to be very important because currently school organizations are receiving the spotlight and assessment from the community as education 
stakeholders, especially in the current era of reformation and openness. The existence of organizational performance measurement, it is expected that bureaucratic organizations can find out the level of success in a certain period, therefore "performance measurement is a management tool used to improve quality. decision making and accountability. "

When it viewed in general, the aspects of concern for measuring organizational performance are: financial, customer satisfaction, internal operations / activities, civil servants' satisfaction, community / stakeholder satisfaction and timeliness. There are at least four key elements of an organizational performance measurement system. The four elements are planning and setting a goal, developing, relevant measures development, reporting the formal result and using information. For every organization, work performance assessment is a very important activity. This assessment can be used to measure the success of an organization within a certain period of time. This assessment can also be used as an input for improvement or enhancement of organizational performance (Keban, 1995). Furthermore, it is said that in government agencies, especially performance appraisal, is very useful for assessing the quantity, quality and efficiency of services, motivating implementing bureaucrats, monitoring contractors, making budget adjustments, encouraging the government to pay more attention to the needs of the people it serves and guide improvements in public services. In performance measurement activities in order to provide real information on various activities that have been carried out by the organization, measurement of indicators requires careful and valid methods. Bellavita et al (in Keban, 1995) suggest that to measure performance effectively or called as the "performance-oriented evaluation" is a performance evaluation activity carried out by a group of evaluators, which not only improves performance but also "search for excellence". This group of evaluators can assess the validity of the indicators used and control any irregularities that can occur when collecting and processing data. There are three concepts offered by Lenvine, et al, 1990 (in Dwiyanto, 1995) that can be used to measure the performance of bureaucratic organizations, namely responsiveness, responsibility and accountability. In general, these terms can be explained as follows:

a) Responsiveness is the ability of an organization to recognize community needs, set service agendas and priorities, and develop public service programs according to community needs and aspirations.

b) Responsibility, is a measure or criterion of the extent to which the implementation of public organization activities is in accordance with the correct implementation of public administration principles or in accordance with organizational policies, both implicit and explicit.

c) Accountability is how much the policies or activities of public organizations are subject to political officials elected by the people (Dwiyanto, 1995).

Based on the previous statement regarding the concepts of bureaucracy and organizational performance, then the meaning contained in the concept of school organizational performance can be formulated, namely the results of the process of management activities carried out by the headmaster which includes coaching, monitoring and supervision activities.

\section{Research Method}

The type of research used in this study is descriptive qualitative research. According to Moleong (2000) "descriptive data is collected in the form of words, pictures, and not numbers". Moleong (2000) also stated that qualitative research is research that intends to understand the phenomena experienced by research subjects, for example behavior, perception, motivation, action, and so on. According to Bogdan and Taylor (Moleong, 2000) a qualitative descriptive research is a research procedure that produces descriptive data in the form of written and spoken words from the people being observed. In this study, the researcher seeks to provide a systematic, factual and accurate description of the conditions that exist at the research location regarding the object under study, where the facts related to these conditions are also presented and based on the existing facts a conclusion will be drawn.

According to Moleong (2000), in qualitative research, things that must be considered are the problem and focus of the research. Focus provides limitations in the study and limitations in data collection, so that with this limitation the researcher will focus on understanding the problems that are the research objectives. Therefore, according to Moleong, the focus of research is intended to limit qualitative studies, as well as limit research in order to choose which data is relevant and which data is not relevant. In accordance with the problems previously described, this research is focused on:

The headmaster' strategy to improve civil servants' performance in the Administration department:

a) Establishing disciplinary rules regarding working hours on time;

b) Building a spirit of togetherness through: friends, superiors and subordinates, as well as communication, intimacy and mutuality respect to each other; and

c) Providing a good example to all civil servants

This research was conducted at Pringgasela Senior High School, East Lombok Regency - NTB. The type of data used in this study is divided into two:

\section{a) Primary data}

Primary data is a data obtained directly from the field or research site through observation, interviews or documentation of research toward informants or sources.

\section{b) Secondary data}

Secondary data is a data obtained or collected by people who carry out research from existing sources. This data is usually obtained from libraries or from previous research reports. The secondary data in this study are documents. The use of secondary data is to strengthen findings and complement the information gathered through observations and interviews. 
According to Lofland (in Moleong, 2000) that "the main data sources in qualitative research are words and actions". Words and actions are sources of data obtained from the field by observing or interviewing. Data collection techniques are the most important step in the research process, because the main purpose of research is to get data. To collect data as accurately as possible about the variables to be studied. Researchers used two data collection techniques:

\section{a) Interview}

An interview is a conversation conducted by two or more people, the interviewer who will ask questions and the interviewee, the person who will be interviewed who will provide answers to the questions that will be asked (Moleong, 2005). Interviews in this study were conducted with the headmaster, vice principals, teachers and administrative staff as informants.

\section{b) Documentation}

According to Herdiansyah (2010) documentation is a method of collecting qualitative data by viewing or analyzing documents created by the subject himself or others about the subject. This method is used to collect data that is already available in document records. This documentation is a technique of collecting data from non-human sources. Sources of data can be photos, letters, daily notes, reports and so on.

Data analysis techniques aim to simplify it into a form that is easier to understand and interpret. Data analysis in this study was carried out by qualitative descriptive method to analyze data by: Data Collection, Data Reduction, Data Presentation, Conclusion Drawing / Data Verification with the arrangement of words and sentences as an answer to the problems studied by Miles et al., 2014). Data analysis is the process of systematically searching and compiling data obtained from interviews, field notes and other materials, so that it can be easily understood and the findings can be informed to everyone. The steps or stages in data analysis used in this study can be described as follows:

a) Data gathering

Data obtained from the results of observations, interviews and documentation are recorded in field notes containing what was seen, heard, felt, witnessed, experienced and also findings about what was found during the research and is a material for data collection plans for the next stage. Researchers conducted interviews with several informants to obtain these notes.

b) Data reduction

Data reduction is defined as the process by which the researcher chooses, focuses attention on simplification, abstracts the research data. This process is also known as the data transformation process, which is the change from "coarse" data that appears from written notes in the field to data that is "fine" and ready for use after selecting, summarizing, classifying into patterns with create research transcripts to emphasize, shorten, focus and then discard unnecessary data. The data that has been reduced will also provide an overview that can make it easier for researchers to retrieve the required data later. Data reduction takes place continuously during the research being carried out.

c) Data presentation

The presentation of data is intended to make it easier for researchers to see research results. By presenting the data, it will be understood what happened, what must be done and further analyzed to take action based on the understanding obtained from the data presentations.

\section{d) Conclusion/ verification}

Is a step to look for the meaning or meaning of phenomena, patterns of configuration explanations, causal pathways and researcher's propositions. Conclusions were also verified throughout the study to find final conclusions. Miles et al. (2014) explains, for this step the researcher begin to look for the meaning of objects, noting regularities, patterns, explanations, possible configurations, causal pathways and propositions. The analysis technique work system mentioned above can be drawn in the following diagram:

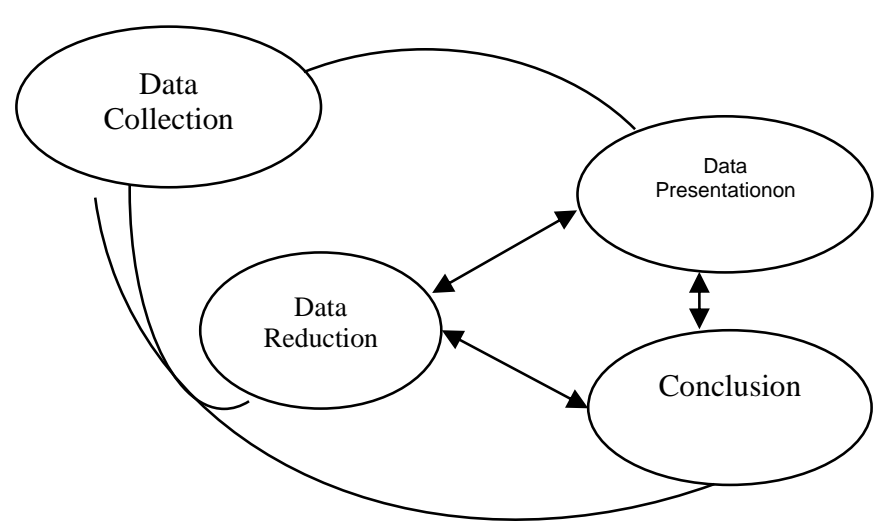

Figure 1. Interactive Model of Data Analysis Source: Miles et al. 2014

Data reduction, data presentation and drawing conclusions are intertwined before, during and after data collection in parallel forms, to build general insights called analysis (Miles et al., 2014). In this connection, every conclusion from the data that has been obtained at the first level is considered a tentative conclusion that needs to be checked and traced continuously from various sources and other information.

\section{Results}

\subsection{The Headmaster's Leadership Strategy at Pringgasela High School}

The role of the headmaster to improve the performance of civil servant is one of the keys to success for the 
success of the entire organization. In improving the performance of civil servant, it is very decisive to direct one's attitudes and behavior to be able to behave in accordance with the rules determined in supporting the achievement of organizational goals. An expression, no matter how sophisticated a work equipment is, the availability of costs and work procedures, if organizational members behave not in accordance with the mission of the organization, it will result in failure to achieve organizational goals. Herein lies the importance of the human factor compared to other resources. Therefore, civil servant as a human resource in an organization must be nurtured, directed and improved in its ability to reinforce its duties and work as a civil servant.

the results of the headmaster's leadership performance strategies at pringgasela high school and their impact on employees include the following:

a) There must be rules regarding discipline when working hours must be on time. For example: entering the office from 07.30 WIB to $15.00 \mathrm{WIB}$, if there are officers who often arrive late, they are subject to sanctions, ranging from light, moderate and heavy sanctions. This rule has a positive impact or influence on all administrative civil servants because they feel they are being cared for by their superiors, this encourages increased employee discipline, even though some of them are still late but rarely come.

b) Togetherness: we will be able to handle activities if togetherness will be well established between employee, both superiors and subordinates and vice versa. They must establish good communication, intimacy and mutual respect for each other. With a togetherness approach to employees by superiors, it improving communication and intimacy between employees and the psychological aspect is getting closer.

c) Becoming the role model of all civil servant, meaning when we ask employee to be disciplined, they want to implement and improve their performance more effectively and efficiently. By showing a good role model for us as a boss, has a big influence and gives positive encouragement to employees.

d) Creating a conducive work atmosphere full of kinship between civil servants and creating a sense of kinship, building high meaning internally inside or outside the office, meetings/ incidents that make it comfortable, even though they never meet to carry out certain tasks outside of school, therefore by gathering, eating together, friendship is maintained.

e) Increasing the welfare or salary of civil servant. Paying attention to the welfare of employees by a leader is a positive thing and can increase the enthusiasm of employees to carry out their duties, this is visible after a performance appraisal is carried out.

f) Providing motivation to civil servants through coaching, training, training, seminars, etc. Giving the opportunity to gain knowledge through education and training, training, seminars is a positive thing, because it will encourage employees to work better and professionally, but there are still employees who are not up to the desired standards. The basis is that if we don't work well, the job will not get success, and vice versa.
Based on the results of the study, it shows that the leadership strategy, especially in improving human resources at pringgasela high school, has not been implemented optimally and the results indicate an increase in performance in either category. This means that efforts are needed to carry out various models in an effort to improve employee performance, in order to achieve better conditions for employees.

The ultimate goal of this performance appraisal is so that all civil servant in terms of work become better so that they are able to encourage work morale, but there are still obstacles faced, namely the lack of responsiveness of the Administrative Apparatus in understanding consumer psychology, the large amount of workload that is carried out in a little bit of time and lack of supporting infrastructure such as: computers, data racks and personnel.

\section{Discussion and conclusion}

The administrative department has shown an increase in good work in providing services such as:

a) The improvement of managerial staff discipline.

b) The improvement spirit of togetherness through friends, superiors and subordinates, as well as communication, intimacy and mutual respect for each other.

c) Conducive work atmosphere and the improvement of work motivation.

d) The improvement of civil servant's motivation to increase their knowledge and skills.

e) Role model encourages them to do better at work.

However, it has not been maximal when they are providing services: either for the satisfaction of teachers, students or interested parties. For example, doing assignments and requests in accordance with what was instructed, has provided a pleasant, friendly attitude to serve and on time if needed.

The constraints raised in this study when performing the performance in providing Administrative Services such as the lack of responsiveness of the Administrative department to understand consumer psychology, the large amount of workload that is carried out in a slightly short time and the lack of supporting infrastructure such as: computers, data rack and personnel.

\section{References}

Alewine, T.C. (2002). Penilaian Kinerja dan Standar Kinerja. PT. Alex Media Komputindo

Bryson, J.M. (1995). Perencanaan Strategis Bagi Organisasi Sosial. Pustaka Pelajar

Dwiyanto, A. (1995). Kinerja Organisasi Publik Kebijakan dan Penerapannya (Makalah), Fisipol UGM.

Herdiansyah, H. (2011). Kualitas Pelayanan Publik. Gaya Media.

Keban T. J. (1995), Capcity Building Sebagai Pra Kondisi dan Langkah Strategis Bagi Perwujudan Otonomi Daerah di Indonesia, JKAP 3(2) 5-19. 
Miles, M.B., Hubberman, M. \& Saldana, J. (2014). Qualitative Data Analysis: A Methods Sourcebook. Sage Publications.

Moleong, L.J. (2000). Metode Penelitian Kualitatif. Remaja Rosda Karya.

Nawawi, H. (2000). Manajemen Strategi Organisai NonProfit Bidang pemerintahan, Gajahmada University Press.

Siagian, S.P. (2003). Manajemen Stratejik. PT. Bumi Aksara.

Wahjosumidjo (2005). Kepemimpinan Kepala Sekolah. Raja Grafindo Persada. 